\title{
Production of antibodies to gliadin in intestinal mucosa of patients with coeliac disease: a study at the single cell level
}

\author{
N LYCKE, A KILANDER, L-Å NILSSON, A TARKOWSKI, AND N WERNER \\ From the Departments of Medical Microbiology, Rheumatology, and Medicine II, University of Göteborg, \\ Göteborg, Sweden
}

SUMMARY Lymphocytes obtained after enzymatic digestion of intestinal biopsies from patients with coeliac disease were examined for the presence of gliadin specific antibody secreting cells by means of the ELISPOT technique. This technique permits enumeration of gliadin antibody secreting immunocytes, differentiated with regard to immunoglobulin class. Patients with coeliac disease were found to have high ( $834 / 10^{6}$ cells) numbers of antigliadin spot forming cells (SFC) in gut mucosa. IgG and IgM antigliadin antibody secreting cells were infrequently shown whereas IgA antigliadin SFC predominated in all patients tested (average $68 \%$ of total SFC). Ten control patients were investigated in parallel with the coeliac patients and showed only low numbers of gliadin antibody secreting cells in gut mucosa $\left(49 / 10^{6}\right.$ isolated cells). Antigliadin antibody secretion by peripheral blood mononuclear cells was shown in only two of six coeliac patients tested and in none of the control patients. The findings suggest that the intestinal mucosa is a major site for antigliadin antibody production and that IgA is the dominating Ig-class of these antibodies. The high sensitivity and accuracy of the ELISPOT technique may provide a useful instrument for future studies of antibody production and regulation of the gut immune response to gluten and other alimentary antigens in coeliac and other intestinal diseases.

Coeliac disease is an enteropathy caused by hypersensitivity to gluten, resulting in villous atrophy of the intestinal mucosa and subsequent malabsorption. ${ }^{1}$ Several studies have provided evidence of abnormal immunological responses to dietary gluten in coeliac patients (for reviews, see $^{23}$ ), but it is poorly understood to what extent immune reactions contribute to the pathogenesis of the disease.

Increased serum antibody levels to gliadin, the alcohol soluble component of gluten, have been documented in several studies of patients with coeliac disease. Particularly the demonstration of gliadin specific antibodies of the IgA isotype has been emphasised as being of great diagnostic value for this

Address for correspondence: Dr N Lycke, Department of Medical Microbiology, University of Göteborg, Guldhedsgatan 10, S-413 46 Göteborg, Sweden.

Received for publication 7 July 1988. disease. ${ }^{46}$ In a series of studies in children as well as in adults we have shown a high diagnostic sensitivity and specificity of combined evaluation of gliadin specific antibodies of the $\operatorname{IgA}$ and $\operatorname{IgG}$ isotypes. ${ }^{7-9}$ The usefulness of determination of such antibodies for the follow up of clinical recovery in coeliac patients subjected to a gluten free diet has also been shown..$^{10}$ More recently, IgG1 and IgG3 antigliadin antibodies have also been suggested to be closely associated with coeliac disease. ${ }^{11}$ Whether antigliadin antibodies in serum reflect an abnormal immune reactivity to gluten in the gut mucosa, the site of the primary lesion of the disease, is, however, not known.

The immunoglobulin production in the intestinal mucosa of patients with coeliac disease has been studied by immunohistochemical methods and by determination in supernatants from cultured mucosal biopsies. Patients with coeliac disease have been found to have increased numbers of IgA- and IgM- 
producing cells in the gut mucosa as compared with healthy controls. ${ }^{12-14}$ Increased numbers of IgGproducing cells have also been shown. ${ }^{14}$ is In accord with the immunohistochemical results an increased production of $\operatorname{IgA}$ and $\operatorname{IgM}$ and in one study also of IgG from cultured biopsies has been reported..$^{16-19}$

The specificity of the locally produced antibodies is less well studied. Falchuk et $a^{20}$ showed for six of seven patients studied before and during gluten challenge that about half of the increase of the $\operatorname{IgA}$ and IgM secretion from mucosal biopsies was attributed to synthesis of gliadin antibodies. Ciclitira et $\mathbf{l}^{19}$ showed increased production of antigliadin specific IgM and IgG but in contrast few patients showed production of specific IgA antibodies. Brandtzaeg and Baklien ${ }^{21}$ found in one patient that about $60 \%$ of the gliadin antibody producing cells were of the $\operatorname{IgA}$ type and $40 \%$ were of the IgG type, whereas no specific IgM antibody producing cells were found. Thus, there is apparent variance in the different studies as to the isotype pattern of total as well as gliadin specific antibody formation from gut mucosa of patients with coeliac disease.

In order to further elucidate the possible contribution of antigliadin antibodies of various isotypes to the pathogenesis of coeliac disease, we have adapted a new method, the ELISPOT technique ${ }^{22}$ for the study of antigliadin antibody synthesis of different isotypes by intestinal lymphocytes at the single cell level. Gut lymphocytes were obtained by enzymatic digestion of duodenal biopsies taken during diagnostic endoscopy.

\section{Methods}

\section{STUDY SUBJECTS}

Ten adult patients of both sexes (age range, 20-66 years) with clinical symptoms characteristic of coeliac disease were, after informed consent, subjected to duodenal biopsies, using biopsy forceps during diagnostic endoscopy. ${ }^{23}$ All patients were untreated at the time of investigation and light microscopy of biopsy specimens showed subtotal villous atrophy. Institution of a gluten free diet resulted in improvement of clinical symptoms in all patients and in nine of the subjects tested to date a significant morphological improvement of the gut mucosa was also observed.

Ten additional patients were included in the study for control purposes. These patients were undergoing routine endoscopy for the investigation of epigastric pain or diarrhoea and none of them had any evidence of small bowel disease. Biopsies, obtained after informed consent, showed normal villous structure.

The studies performed were approved by the Ethical Committee of the University of Göteborg.
PREPARATION OF SINGLE CELL LYMPHOCYTE SUSPENSIONS FROM DUODENAL BIOPSIES

Intestinal cells were isolated from gut biopsies according to a previously described method elaborated in mice for the extraction of intestinal lamina propria cells. ${ }^{24}$ Briefly, biopsies were placed immediately after sampling in calcium and magnesium free Hank's balanced salt solution (HBSS) (Gibco, Paisley, Scotland). The biopsies were weighed and cut into $1-2 \mathrm{~mm}^{3}$ pieces and rinsed repeatedly in HBSS. The pieces were then incubated at room temperature for 15 minutes in HBSS containing $1 \mathrm{mM}$ dithiothreitol (DTT) (Sigma Chemical Company, St Louis, Mo), gentamycin and $10 \%$ fetal calf serum (FCS) (Gibco). After washes in HBSS the epithelial cells together with intraepithelial lymphocytes (IEL) were removed by four consecutive 15 minute incubations at room temperature in HBSS with $5 \mathrm{mM}$ ethylene-diaminetetraaceticacid (EDTA) (Merck, Darmstadt, W Germany) under constant stirring. The four fractions of cell suspensions obtained were pooled and passed through siliconised glass wool followed by washing twice in HBSS. This fraction, containing the IEL, were kept on ice until assayed. The remaining pieces of gut mucosa were then treated with collagenase (40 IU/ml) (type C-2139, Sigma) in RPMI 1640 without sodium bicarbonate (Flow Laboratories, Irvine, Scotland) supplemented with $20 \%$ FCS and gentamycin and incubated at $37^{\circ} \mathrm{C}$ for 30 minutes under magnetic stirring $(100 \mathrm{rpm})$ in order to release lymphoid cells from the lamina propria. This treatment was repeated twice. The cell fractions thus obtained were filtered through glass wool and pooled with the IEL containing suspension. The described procedure provided a lymphoid cell suspension, contaminated with only $10-30 \%$ epithelial cells, and thereby allowing analysis of antibody production by single cells. Cell viability always exceeded $90 \%$ as determined by trypan blue dye exclusion. The cells were finally suspended at appropriate cell density in Iscove's medium (Gibco) with 5\% FCS.

PREPARATION OF MONONUCLEAR CELL SUSPENSIONS FROM PERIPHERAL BLOOD Peripheral blood mononuclear cells were isolated by gradient centrifugation of heparinised blood on Lymphoprep TM (Nyegaard, Oslo, Norway) according to Böyum. ${ }^{25}$

DETECTION OF GLIADIN SPECIFIC ANTIBODY SECRETING CELLS BY THE ELISPOT ASSAY The ELISPOT technique as described by Czerkinsky et $a l^{22}$ was used for assaying single cell suspensions of lymphocytes obtained by enzymatic digestion of gut mucosa with regard to isotype specific antigliadin 
antibody production. Crude gliadin (Sigma), dissolved in a minimal amount of methanol followed by dilution to $200 \mu \mathrm{g} / \mathrm{ml}$ in phosphate buffered saline (PBS), was used for coating of polystyrene Petri dishes $(5 \mathrm{~cm}$ diameter) (Nunclon, Nunc, Roskilde, Denmark). ${ }^{26}$ Dishes coated with irrelevant antigens (cholera toxin and keyhole limpet haemocyanin (KLH) respectively) were prepared for control purposes as previously described. ${ }^{24}$ Between $1-5 \times 10^{5}$ cells were analysed in each Petri dish and at least four Petri dishes were assayed per patient. After four hours incubation at $37^{\circ} \mathrm{C}, 10 \% \quad \mathrm{CO}_{2}$ and $90 \%$ humidity, the Petri dishes were rinsed with PBS containing $\mathbf{0 . 0 5 \%}$ Tween 20 (PBS-Tween) followed by the addition of developing antiserum. For each patient single or duplicate Petri dishes were developed using horseradish peroxidase (HRP) conjugated antihuman immunoglobulins (Dakopatts A/S, Glostrup, Denmark) specific for $\operatorname{IgG}, \operatorname{IgA}$, and IgM, repspectively. A mixture of these three antibody preparations was used to determine the total number of spot forming cells (SFC). When only single Petri dishes for total Ig and isotype specific antigliadin SFC could be analysed, the sum of the various isotype specific SFC equalled the number of total Ig-anti-gliadin SFC observed. All antisera were diluted 1/200 in PBS-Tween before use. The specificity of the conjugates was checked by the double diffusion-in-gel technique using highly purified immuoglobulin preparations of the various isotypes. ${ }^{27}$ Conjugate incubation was carried out overnight at room temperature. After thorough washing in PBS, bound antibodies were visualised by adding the enzyme substrate, $0.01 \% \quad \mathrm{H}_{2} \mathrm{O}_{2}$ and paraphenylenediamine $(0.5 \mathrm{mg} / \mathrm{ml})$ in $1 \%$ PBS-agar, as a thin film. Spots, appearing within 30 minutes, were counted under low magnification.

STATISTICAL ANALYSIS

The Wilcoxon's rank-sum test was used for calculation of statistical significance of differences in SFC values of coeliac as compared with control patients.

\section{Results}

ANTI-GLIADIN IMMUNOGLOBULIN PRODUCTION BY GUT LYMPHOCYTES

In preliminary studies the procedure for assay of antigliadin production by isolated gut lymphocytes from coeliac patients was established including determination of number of duodenal biopsies needed, recovery of lymphocytes per patient, determination of optimal conditions for antigen coating and incubation in the ELISPOT assay, as well as evaluation of the specificity and working dilutions of developing antisera. Because of varying recovery of
Table Antigliadin antibody secreting cells isolated from gut mucosa* and from peripheral blood from coeliac patients

\begin{tabular}{|c|c|c|c|c|c|}
\hline \multirow[b]{2}{*}{$\begin{array}{l}\text { Coeliac } \\
\text { patient }\end{array}$} & \multicolumn{2}{|c|}{$\begin{array}{l}\text { Antigliadin } S F C / 10^{\circ} \\
\text { lymphocytes }\end{array}$} & \multirow[b]{2}{*}{$\begin{array}{l}\text { Control } \\
\text { patient }\end{array}$} & \multicolumn{2}{|c|}{$\begin{array}{l}\text { Antigliadin } S F C / 10^{\circ} \\
\text { lymphocytes }\end{array}$} \\
\hline & $\begin{array}{l}\text { Gut } \\
\text { mucosa }\end{array}$ & $\begin{array}{l}\text { Peripheral } \\
\text { blood }\end{array}$ & & $\begin{array}{l}\text { Gut } \\
\text { mucosa }\end{array}$ & $\begin{array}{l}\text { Peripheral } \\
\text { blood }\end{array}$ \\
\hline 1 & 430 & nd & 1 & 0 & nd \\
\hline 2 & 380 & nd & 2 & 50 & nd \\
\hline 3 & 150 & nd & 3 & 0 & nd \\
\hline 4 & 790 & nd & 4 & 70 & nd \\
\hline 5 & 520 & 1 & 5 & 30 & 0 \\
\hline 6 & 780 & 0 & 6 & 100 & 0 \\
\hline 7 & 960 & 0 & 7 & 70 & 0 \\
\hline 8 & 1030 & 4 & 8 & 40 & nd \\
\hline 9 & 1690 & 102 & 9 & 50 & 0 \\
\hline 10 & 1610 & 59 & 10 & 80 & 0 \\
\hline Mean (SD) & \multicolumn{2}{|c|}{$834(509)$} & & $49(33)$ & \\
\hline
\end{tabular}

* Single cell suspensions were prepared from gut biopsies by enzymatic extraction. Antigliadin producing cells (SFC) were shown by means of the ELISPOT technique. Cells from each individual were assayed in gliadin coated Petri dishes using a mixture of HRPconjugated antihuman IgG-, IgM-, and IgA-immunoglobulins as developing antiserum. $n d=$ not done.

lymphocytes from the intraepithelial and lamina propria compartments between individuals as well as great variation of registered specific antibody secreting cells in the two compartments, gut lymphocytes were pooled before being analysed by ELISPOT. From each patient an average of 10 small biopsies was taken, constituting a total wet weight of $50-250 \mathrm{mg}$ (mean 144), from which $4-30 \times 10^{5}$ (mean $6 \times 10^{5}$ ) lymphoid cells were isolated.

A minimum of 100000 cells were applied to each Petri dish, and analysed for antigliadin production. The antigen specificity of the ELISPOT assay was shown by the failure of the gut lymphocytes to give rise to spots on Petri dishes coated with cholera toxin or keyhole limpet haemocyanin. The detection of antigliadin SFC was dependent on the active synthesis of immunoglobulin in vitro, as indicated by the finding that gut lymphocytes plated on Petri dishes incubated at $+4^{\circ} \mathrm{C}$ did not give rise to any spots.

On the first five occasions that the assay procedure was done one coeliac and one control patient were analysed in parallel (Table, patients 1-5). In these five as well as in the subsequent five coeliac patients investigated high numbers of antigliadin producing gut lymphocytes were found in contrast with the control patients (Table) $(\mathrm{p}<0 \cdot 001)$.

ISOTYPE DISTRIBUTION OF ANTIGLIADIN PRODUCING GUT LYMPHOCYTES

Gut lymphocytes from eight of the 10 coeliac patients were analysed with regard to isotype distribution of gliadin antibody SFC (Figure). A clear dominance of 


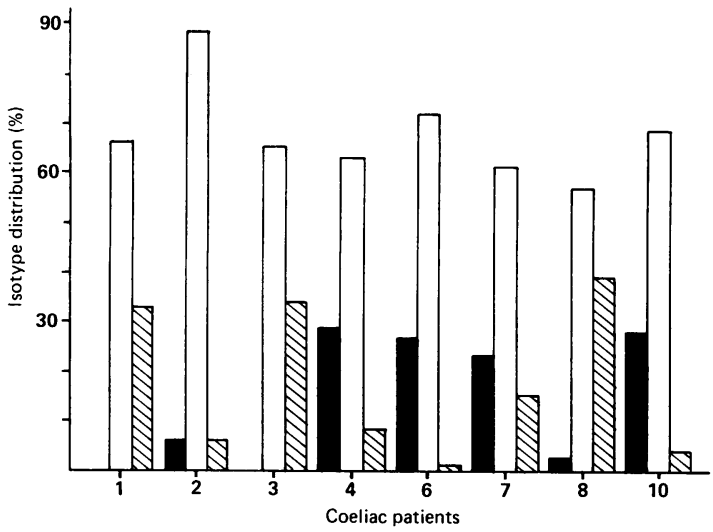

Figure Isotype distribution in \% of total antigliadin SFC by gut lymphocytes in eight of 10 coeliac patients. Cells from each individual were assayed by the ELISPOT technique in gliadin coated Petri dishes using isotype specific HRP. conjugated antihuman immunoglobulin preparations as

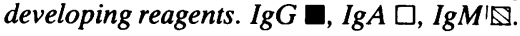

IgA antigliadin producing cells was found in all patients, frequencies ranging from $58-88 \%$ of the total number of antigliadin SFC (mean $68 \%$ ). IgMproducing cells constituted approximately one third of the antigliadin SFC in three of the eight patients whereas IgG-producing cells were noted at a frequency of $30 \%$ in four of the patients (Figure).

\section{ANTIGLIADIN ANTIBODY PRODUCTION BY}

PERIPHERAL BLOOD MONONUCLEAR CELLS

Only two of six coeliac patients tested showed significant spontaneous production of antigliadin antibodies by peripheral blood mononuclear cells (Table). Interestingly, these patients were also the ones who had the highest numbers of antigliadin producing cells in their gut mucosa. None of five control patients analysed showed any antigliadin antibody producing cells in peripheral blood.

\section{Discussion}

In this study we demonstrate the production of antigliadin antibodies of the $\operatorname{IgA}$, IgG, and IgM isotypes by single lymphocytes isolated from the gut of coeliac patients. The gut mucosa obtained from coeliac patients contained significantly higher numbers of antigliadin antibody producing cells than that from non-coeliac individuals. Whether such high levels of antigliadin producing cells in gut mucosa is a unique feature for coeliac disease is, however, not clear from this study since no patients with small intestinal diseases other than coeliac disease were included for comparison.
In agreement with Falchuk and Strober ${ }^{20}$ we found a clear dominance of IgA antigliadin antibody production whereas in contrast with their data a less pronounced IgM antigliadin antibody formation was observed. IgG antigliadin SFC were seen in four of eight patients but specific SFC of this isotype did never predominate in any of these studied. Our data are at some variance with the strong IgG antigliadin formation in gut found by Brandtzaeg and Baklien ${ }^{21}$ as well as with the results of Ciclitira $e t$ al ${ }^{19}$ who reported increased gliadin antibody production largely of the IgG and IgM isotypes in supernatants after in vitro culture of gut biopsies from coeliac as compared with control patients.

By measuring antigliadin formation in the gut mucosa at the single cell level rather than indirectly by ELISA of intestinal secretions or culture supernatants of organ cultures several advantages are achieved. First, there is no risk of measuring contaminating serum or bile antibodies. Second, the sensitivity of the ELISPOT assay done with isolated lymphocytes is very high as has been shown in a previous study ${ }^{22}$ and thus operates over a wider range which allows better differentiation between even relatively weak responses as compared with, for example ELISA of culture supernatants. In addition the level of antigliadin production from gut mucosa is expressed as number of specific cells per total number of lymphoid cells recovered and not as per wet weight tissue or per total Ig secreted in culture which both make determinations uncertain with great variation in values between individual patients. ${ }^{18}{ }^{19}$ Third, this method would allow in vitro stimulation of gut lymphocytes by specific antigen and thereby enable the study of immune regulation by $\mathrm{T}$ cells in coeliac patients.

A limiting factor in this study was the number of lymphoid cells that could be recovered from the biopsies obtained from each individual. On average, $6 \times 10^{5}$ cells could be recovered, a number sufficient for assaying Ig-isotypes and total anti-gliadin SFC on single Petri dishes only. In all instances, the sum of antigliadin SFC of the different isotypes equalled the number of total antigliadin SFC. With an improved biopsy sampling procedure, however - that is, a greater number of biopsies per patient, a more detailed analysis of isotype and Ig subclass pattern could be performed.

Because it was not possible to evaluate the reproducibility of the method in the same individual, we attempted to control for experimental variability by assaying a coeliac and a control patient in parallel on five occasions. It was found that $C D$ patient cells consistently yielded significantly higher antigliadin SFC activity as compared with cells obtained from control patients. 
The magnitude of the antigliadin antibody response observed in this study is noteworthy and it may be compared with antigen specific peak SFC responses registered in lamina propria after oral immunisations of mice with the potent antigen cholera toxin. ${ }^{24}$

Neither IgM nor IgG anti-gliadin SFC were consistently seen in our coeliac patients. With regard to a possible immunopathological role of local antigliadin production in gut mucosa it would seem less likely that abnormal IgG or IgM responses to gliadin with complement or Fc-receptor mediated destruction of mucosal tissues would play a primary role in the disease as previously been suggested. ${ }^{23}$ The high titres of IgG antigliadin in serum in untreated coeliac patients or the sequential increase by time of such antibodies in serum of children with coeliac diease $^{41013}$ might rather reflect altered intestinal permeability. The occurrence of such a systemic exposure to gliadin was suggested by the two coeliac patients showing antigliadin SFC among peripheral blood mononuclear cells. These two patients also had the highest intestinal SFC numbers.

The fact that IgA deficient individuals can develop coeliac disease $^{28}$ may suggest that cell mediated immune mechanisms may be operating in coeliac disease. If an adverse response to gliadin in the gut in susceptible individuals is the cause of tissue damage this could be the result of abnormal $T$ cell regulation of local mucosal immune responses. ${ }^{2}$ Whether such a defect is the result of a gliadin specific suppressor $T$ cell dysfunction in coeliac patients as supported by the findings of Corazza et al,,$^{29}$ or is a consequence of yet other mechanisms, is not known.

The method presented here might provide a useful instrument for further study of cell mediated immunity and antibody production and its control mechanisms in the gut mucosa of patients with coeliac disease.

We thank Lena Ekman, Ulla Karlsson, Ella Olofsson, and Lena Svensson for skilled technical assistance. Our thanks are also due to Dr C Åhrén for histological evaluation of biopsy specimens. This study was supported by grants from the Swedish Medical Research Council, the Swedish Society of Medicine, the Gothenburg Medical Society, and the Ellen, Walter, and Lennart Hesselman Foundation.

\section{References}

1 Cooke WT, Holmes GKT. Cocliac disease. Edinburgh: Churchill Livingstone, 1984.

2 Strober W. Gluten sensitive enteropathy. An abnormal immunologic response of the gastrointestinal tract to a dietary protein. In: Shorter RG, Kirsner JB, eds. Gastrointestinal immunity for the clinician. Orlando Florida: Grune and Stratton, 1985: 75-112.
3 Scott H, Brandtzaeg P, Thorsby E, Baklien K, Fausa O, Ek J. Mucosal and systemic immune response patterns in celiac disease. Ann Allergy 1983; 51: 233-9.

4 Unsworth DJ, Walker-Smith JA, Holborow EJ. Gliadin and reticulin antibodies in childhood coeliac disease. Lancet 1983; i: 874.

5 Savilahti E, Viander M, Perrkiö M, Vainio E, Kalino K, Reunala T. IgA antigliadin antibodies: a marker of mucosal damage in childhood coeliac disease. Lancet 1983; i: 320-2.

6 Scott H, Fausa O, Ek J, Brandtzaeg P. Immune response patterns in coeliac disease. Serum antibodies to dietary antigens measured by an enzyme linked immunosorbent assay (ELISA). Clin Exp Immunol 1984; 57: 25-32.

7 Kilander AF, Dotevall G, Fällström SP, Gillberg RE, Nilsson L-Å, Tarkowski A. Evaluation of gliadin antibodies for detection of coeliac disease. Scand J Gastroenterol 1983; 18: 377-83.

8 Stenhammar L, Kilander AF, Nilsson L- $\AA$, Strömberg L, Tarkowski A. Serum gliadin antibodies for detection and control of childhood coeliac disease. Acta Paediatr Scand 1984; 73: 657-63.

9 Lindberg T, Nilsson L-Å, Borulf S, et al. Serum IgA and IgG gliadin antibodies and small intestinal mucosal damage in children. J Pediatr Gastroenterol Nutr 1985; 4: $917-22$.

10 Kilander AF, Nilsson L-Å, Gillberg R. Serum antibodies to gliadin in coeliac disease after gluten withdrawal. Scand J Gastroenterol 1987; 22: 29-34.

11 Husby S, Foged N, Oxelius A, Svehag S-E. Serum IgG subclass antibodies to gliadin and other dietary antigens in children with coeliac disease. Clin Exp Immunol 1986; 64: 526-35.

12 Savilathi E. Intestinal immunoglobulins in children with coeliac disease. Gut 1972; 13: 958-64.

13 Baklien K, Brandtzaeg P, Fausa O. Immunoglobulins in jejunal mucosa and serum from patients with adult coeliac disease. Scand J Gastroenterol 1977; 12: 149-59.

14 Scott BB, Goodall A, Stephenson P, Jenkins D. Small intestinal plasma cells in coeliac disease. Gut 1984; 25 : $41-6$.

15 Lancaster-Smith M, Kunar P, Marks R, Clark ML, Dawson AM. Jejunal mucosal immunoglobulin containing cells and jejunal fluid immunoglobulins in adult coeliac disease and dermatitis hepatiformis. Gut 1974; 15: 371-6.

16 Loeb PM, Strober W, Falchuk ZM, Laster L. Incorporation of L-leucine $-\mathrm{C}^{14}$ into immunoglobulins by jejunal biopsies of patient with celiac and other gastrointestinal diseases. J Clin Invest 1971; 50: 559-69.

17 Fluge G, Aksnes L. Quantification of immunoglobulins after organ culture of human duodenal mucosa. J Pediatr Gastroenterol Nutr 1983; 2: 62-70.

18 Wood GM, Shires S, Howdle PD, Losowsky MS. Immunoglobulin production by coeliac biopsies in organ culture. Gut 1986; 27: 1151-60.

19 Ciclitira PJ, Ellis HJ, Wood GM, Howdle PD, Losowsky MS. Secretion of gliadin antibody by coeliac jejunal mucosal biopsies cultured in vitro. Clin Exp Immunol 1986; 64: 119-24. 
20 Falchuk MZ, Strober W. Gluten-sensitive enteropathy: Synthesis of anti-gliadin antibody in vitro. Gut 1974; 15: 947-52.

21 Brandtzaeg P, Baklien K. Immunohistochemical studies of the formation and epithelial transport of immunoglobulins in normal and diseased human intestinal mucosa. Scand J Gastroenterol [suppl 36] 1976; 11: 1-45.

22 Czerkinsky CC, Nilsson L-Å, Nygren H, Ouchterlony Ö, Tarkowski A. A solid-phase enzyme-linked immunospot (ELISPOT) assay for enumeration of specific antibody-secreting cells. J Immunol Methods 1983; 65: 109-21.

23 Gillberg R, Åhrén C. Coeliac disease diagnosed by means of duodenoscopy and endoscopic duodenal biopsy. Scand J Gastroenterol 1977; 12: 911-6.

24 Lycke N. A sensitive method for the detection of specific antibody production in different isotypes from single lamina propria plasma cells. Scand J Immunol 1986; 24: 393-403.

25 Böyum A. Isolation of mononuclear cells and granulocytes from human blood. Scand J Clin Lab Invest [suppl 97] 1968; 21: 27.

26 Nilsson L-Å. Gliadin antibodies. In: Bergmeyer HU, ed. Methods of enzymatic analysis. Weinheim: $\mathrm{VCH}, 1986$ : 214-23.

27 Lycke N, Hellström U, Holmgren J. Circulating cholera antitoxin memory cells in the blood one year after oral cholera vaccination in humans. Scand J Immunol 1987; 26: 207-11.

28 Asquith P, Thompson RA, Cooke WT. Serumimmunoglobulins in adult coeliac disease. Lancet 1969; ii: $129-31$.

29 Corazza GR, Sarchielli P, Londie M, Frisoni M, Gasbarrini G. Gluten specific suppressor T cell dysfunction in coeliac disease. Gut 1986; 27: 392-8. 